\title{
Komparasi Zakat Profesi dalam Agama Islam dan Persepuluhan dalam Agama Kristen Protestan
}

\author{
Gin Gin Muhamad Ridwan \\ Jurusan Studi Agama-Agama \\ Fakultas Ushuluddin UIN Sunan Gunung Djati Bandung, Indonesia \\ gingin_ridwan@yahoo.com
}

\begin{abstract}
This study aims to discuss the similarities and differences between professional zakat in Islam and tithing in Christianity. This research method is a qualitative type through library research and field studies by applying comparative descriptive analysis. The results and discussion of this study indicate that professional zakat in Islam and tithing in Christianity both originate from the holy books of each religion, it is found that there are similarities and differences between professional zakat in Islam and tithing in Christianity, and the meeting point of both has implications for the development of religious philanthropy in Indonesia. This study concludes that tithing is required in Malachi 3:1011 and professional zakat is required in QS al-Baqarah verse 267 where the wisdom of both is for the benefit of the people or congregation, while the difference is that tithing can be carried out by anyone and professional zakat can only be implemented by people who have reached nishab, and the first aims to return God's gift and the second aims to clean up wealth.
\end{abstract}

Keywords: Christianity, Comparative, Islam, Persepuluhan, Zakat.

\begin{abstract}
Abstrak
Penelitian ini bertujuan untuk membahas persamaan dan perbedaan antara zakat profesi dalam Islam dan persepuluhan dalam Kristen. Metode penelitian ini merupakan jenis kualitatif melalui studi pustaka dan studi lapangan dengan menerapkan analisis deskriptif komparatif. Hasil dan pembahasan penelitian ini menujukan bahwa zakat profesi dalam agama Islam dan persepuluhan dalam agama Kristen keduanya bersumber dari kitab suci masing-masing agama tersebut, ditemukan terdapat pesamaan dan perbedaan antara zakat profesi dalam agama Islam dan persepuluhan dalam agama Kristen, dan titik temu keduanya
\end{abstract}


memiliki implikasi bagi pengembangan filantropi agama di Indonesia. Penelitian ini menyimpulkan bahwa persepuluhan diwajibkan dalam Maleakhi 3:10-11 dan zakat profesi diwajibkan dalam Q.S al-Baqarah ayat 267 dimana hikmah dari keduanya adalah untuk kepentingan umat atau jemaat, sedangkan perbedaannya ialah persepuluhan dapat dilaksanakan oleh siapapun dan zakat profesi hanya bisa dilaksanakan oleh orang yang sudah mencapai nishab, dan yang pertama bertujuan untuk mengembalikan karunia Tuhan dan yang kedua bertujuan untuk membersihkan harta.

Kata kunci: Islam, Komparatif, Kristen, Persepuluhan, Zakat.

\section{Pendahuluan}

Agama dalam Kamus Besar Bahasa Indonesia didefinisikan sebagai sebuah peraturan yang bersifat mengikat seseorang dalam melaksanakan peribadatan kepada Tuhan Yang Maha Esa (KBBI, 2021). Peribadatan tersebut diimplementasikan dalam tindakan baik itu yang langsung berhubungan dengan Tuhan ataupun berhubungan dengan Tuhan sekaligus dengan manusia. Salah satu peribadatan yang berhubungan dengan Tuhan dan manusia adalah zakat di dalam agama Islam (Syafiq, 2016) dan persepuluhan dalam agama Protestan. Zakat dalam Islam terbagi menjadi beberapa bagian salah satunya adalah zakat profesi (Baznas, 2019). Selain dalam hukum tekstual agama, zakat profesi juga diatur dalam teks aturan negara yang tercatat dalam Peraturan Menteri Agama No. 52 tahun 2014. Sedangkan Persepuluhan dalam agama Protestan merupakan persembahan yang diperintahkan Tuhan untuk dibawa kerumah perbendaharaan (Maleakhi, 3:10). Berbeda dengan zakat profesi dalam Islam, persepuluhan dalam agama Protestan tidak tercatat dalam aturan negara.

Selain perbedaan tersebut, penulis menemukan juga perbedaan yang bersumber dari beberapa tulisan-tulisan yang kemudian tulisan tersebut menjadi kajian pustaka penulis dalam menulis artikel ilmiah ini. Antara lain perbedaan yang dituangkan oleh Muh Ichsan dalam skripsi berjudul "Zakat Mal dalam Agama Islam dan Persepuluhan dalam Agama Kristen: Studi terhadap Lembaga Inisiatif Zakat Indonesia dan GPIB Bukit Zaitun Di Kota Makassar." Perbedaan tersebut di antaranya adalah dampak yang dihasilkan apabila seseorang tidak melaksanakan zakat profesi untuk orang Islam atau persepuluhan untuk orang Protestan, tujuan dari pelaksanaan ajaran tersebut, kriteria orang yang berhak melaksanakan ajaran agama tersebut dan pendistribusian Zakat Profesi atau Persepuluhan (Ichsan, 2017). Sedangkan dalam tulisan lain yaitu karya 
Dolfinus Salossa disebutkan dalam bukunya yang berjudul "Korban Persembahan dan Perpuluhan dengan Pengelolaan Perbendaharaan Rumah Tuhan dalam Sistem Rasuli Perjanjian Baru" bahwa persepuluhan ini sangat penting untuk dilakukan mengingat banyaknya contoh yang diberikan oleh tokoh agama pada saat itu seperti raja Salem yang bersumber dari kitab suci untuk melaksanakan persepuluhan "Melkisedek, raja Salem membawa roti dan anggur ia seorang imam Allah Yang Mahatinggi. Lalu ia memberkati Abram, katanya: "Diberkatilah kiranya Abram oleh Allah Yang Mahatinggi, Pencipta langit dan bumi, dan terpujilah Allah Yang Mahatinggi, yang telah menyerahkan musuhmu ke tanganmu." Lalu Abram memberikan kepadanya sepersepuluh dari semuanya" (Kejadian, 14:18-20). Selain menjelaskan anjuran persepuluhan sebagaimana yang telah dilakukan oleh raja terdahulu, persepuluhan, dalam buku tersebut juga menjelaskan bahwa peribadatan tersebut sangat penting bagi umat Tuhan (Imamat, 27:30). Sedangkan dalam Kitab lain dijelaskan bahwa dana persepuluhan digunakan sebagai dana perbendaharaan rumah Tuhan (Maleakhi, 3:10) dan jaminan hamba-hamba Tuhan (Bilangan K. , 18:21).

Berbagai penelitian terdahulu bermanfaat bagi penyusunan kerangka berpikir penelitian ini. Dijelaskan dalam al-Kitab, orang yang pertama kali melakukan persepuluhan adalah Abraham (Kejadian, 14:18-20). Selanjutnya perintah persepuluhan tersebut juga dilakukan oleh Moses yang juga menyerukan umatnya untuk melaksanakan persepuluhan (Kolase, 2:13-14). Namun dalam ayat tersebut disebutkan bahwa yang berhak melakukan persepuluhan adalah kaum Moses sedangkan kaum setelah Moses tidak diserukan untuk melaksanakan persepuluhan dengan alasan persepuluhan merupakan anjuran untuk kaum Moses (Ibrani, 7:518). Di samping itu, ada beberapa pendapat mengenai kewajiban umat setelah Moses (Umat Jesus/Kristiani) untuk melaksanakan persepuluhan. Mereka yang menganggap mewajibkan persepuluhan mengacu pada adanya pertemuan di Kota Tours pada tahun 567 Masehi (Anonim, 2021).

Sementara itu, agama Islam menjelaskan dalam Al-Qur'an bahwa perintah melaksanalan zakat disebutkan sebanyak 32 kali dalam Al-Qur'an. Zakat pertama kali diperintahkan oleh Allah adalah pada tahun kedua Hijriah tidak jauh dengan waktu diperintahkannya puasa. Zakat merupakan perintah yang menjadi rukun dalam ajaran agama Islam. Dalam pelaksanaannya, zakat terbagi menjadi beberapa bagian salah satunya adalah zakat profesi (Baznas, 2019). Adapun yang menjadi landasan pelaksanaan zakat profesi adalah tercantum dalam Q.S at-Taubah ayat 103 yang artinya "Ambillah zakat dari sebagian harta mereka. Dengan zakat itu kamu membersihkan dan mensucikan mereka dan berdo'alah dengan mereka. Sesungguhnya doa kamu itu menjadi ketentraman jiwa bagi mereka. Dan Allah Maha Mendengar lagi Maha Mengetahui" (at- 
Taubah, 103). Selain itu, disebutkan juga perintah melaksanakan zakat profesi dalam Q.S al-Baqarah ayat 267 yang artinya "Hai orang-orang beriman, nafkahkanlah (di jalan Allah) sebagian dari hasil usahamu yang baik-baik, ...." (Baznas, 2019). Selebihnya ditegaskan, "Hai orang orang beriman, berinfaqlah dari hasil kerja kalian yang baik baik dan hasil bumi yang kalian dapatkan seperti pertanian, tambang dan sebagainya. Janganlah kalian sengaja berinfaq dengan yang buruk-buruk. Padahal kalian sendiri kalau diberikan yang buruk seperti itu, akan mengambilnya dengan memicingkan mata seakan tidak ingin memandang keburukannya. Ketahuilah Allah tidak membutuhkan sedekah kalian. Dia berhak untuk dipuji karena kemanfaatan dan kebaikan yang telah ditunjuki-Nya (Tafsirq, 2021).

Selain disebutkan dalam Al-Qur'an, zakat juga disebutkan juga dalam hadits. Ketika itu Nabi memerintahkan Muadz yang pada saat itu ia hendak pergi ke Yaman untuk berdakwah "Dari Ibnu Abbas ra. Bahwasanya Nabi Saw mengutus Muadz ke Yaman, lalu menuturkan is hadisnya, dan di dalamnya disebutkan, "Sesungguhnya Allah telah mewajibkan zakat kepada mereka pada harta mereka yag diambil dari orang kaya mereka dan diberikan kepada orang-orang miskin mereka" (H.R. Bukhori Muslim). Berkenaan dengan pelaksanaan persepuluhan dan zakat profesi, seseorang akan mengikuti tuntunan kitab suci dan tokoh agama. Dari keduanya terdapat perbedaan dan persamaan dalam pelaksanaannya.

\section{Bagan 1. Kerangka Berpikir}

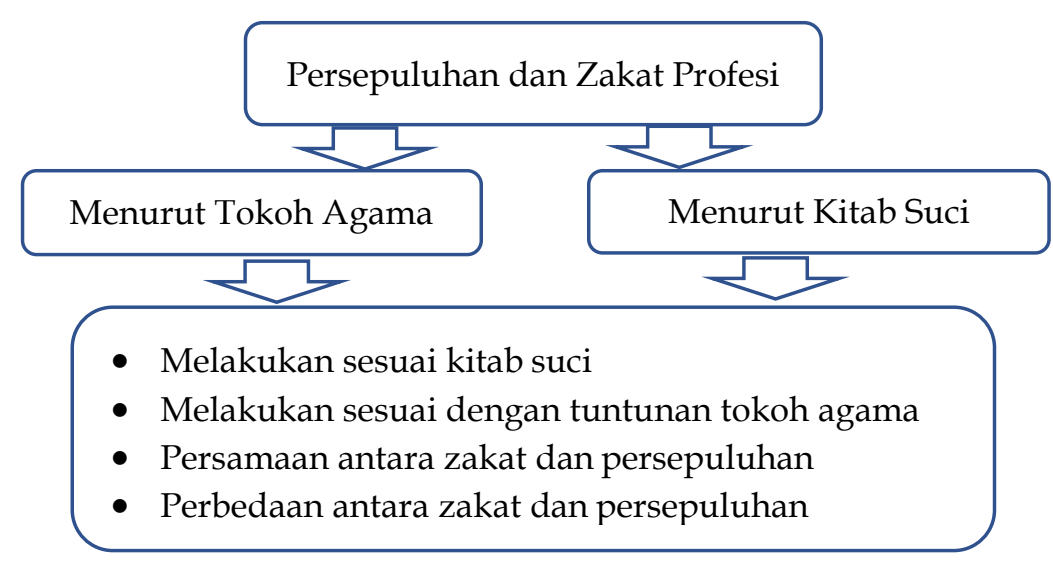

Berdasarkan kerangka berpikir pada Bagan 1 di atas, penulis berusaha menyusun formula penelitian, yaitu rumusan masalah, pertanyaan penelitian, dan tujuan penelitian (Darmalaksana, 2020). Rumusan masalah penelitian ini adalah terdapat persamaan dan perbedaan antara zakat profesi dalam Islam dan persepuluhan dalam Kristen. Pertanyaan utama 
penelitian ini ialah bagaimana persamaan dan perbedaan antara zakat profesi dalam Islam dan persepuluhan dalam Kristen. Adapun tujuan penelitian yaitu membahas persamaan dan perbedaan antara zakat profesi dalam Islam dan persepuluhan dalam Kristen. Penelitian ini diharapkan memiliki implikasi manfaat khususnya dalam kajian studi agama-agama di Indonesia.

\section{Metode Penelitian}

Penelitian ini merupakan jenis kualitatif melalui studi pustaka dan studi lapangan (Darmalaksana, Metode Penelitian Kualitatif Studi Pustaka dan Studi Lapangan, 2020). Studi Pustaka dilakukan dengan menghimpun sumber kepustakaan dari ajaran Islam dan dari ajaran Kristen. Sedangkan studi lapangan dilakukan melalui pengamatan, dokumentasi, dan wawancara (Darmalaksana, 2020). Adapun studi lapangan dilaksanakan di Gereja Pantekosta Maranatha Cimahi dan di BAZNAS Kota Cimahi.

Penelitian ini menerapkan metode deskriptif komparatif dengan tujuan mendapatkan data yang lebih mendalam, akurat, efektif dan valid. Metode deskriptif komparatif digunakan penulis dalam rangka menganalisa, memahami tindakan keberagamaan umat beragama dalam pelaksanaan peribadatan persepuluhan pada umat di lingkungan Gerakan Gereja Pantekosta Maranatha Kota Cimahi dan pelaksanaan zakat profesi pada umat di lingkungan Badan Amil Zakat Nasional Kota Cimahi.

Adapun tindakan keberagaman tersebut dibagi dalam beberapa poin. Pertama, sumber hukum pada peribadatan persepuluhan dan zakat profesi. Pada poin ini penulis menganalisa, memahami pernyataan kitab suci mengenai persepuluhan dan zakat yang kemudian akan direfleksikan dalam tindakan keberagamaan. Menganalisa dan memahami umat yang melaksanakan peribatan tersebut dan menganalisa alasan umat yang belum tergerak untuk melaksanakan peribadan tersebut. Kedua, perspektif tokoh agama dalam menyikapi peribadatan persepuluhan dan zakat profesi. Pada poin kedua, penulis menganalisa, memahami pernyataan tokoh agama dalam memahami persepuluhan dan zakat profesi. Lebih jauh, penulis menganalisa pernyataan tokoh agama tersebut dan membandingkannya dengan pernyataan kitab suci untuk mengetahui korelasi antara keduanya yakni kitab suci dan pemahaman atau penafsiran tokoh. Ketiga, tindakan keberagamaan umat dan tokoh agama. Pada poin ini, penulis melakukan pengamatan lanjutan setelah sebelumnya melakukan analisa dan pemahaman dengan melihat langsung realitas umat beragama dalam tindakan mereka setelah mengetahui sumber hukum dan penjelasan tokoh agama dalam peribadatan persepuluhan dan zakat profesi.

Jika terdapat perbedaan antara pernyataan kitab suci dan pernyataan tokoh dalam tindakan keberagamaan seseorang, penulis akan melakukan 
pengamatan lebih jauh kepada umat beragama tersebut dengan memahami pemikirannya tentang peribadatan tersebut. Selanjutnya umat beragama tersebut melaksanakan peribadatan persepuluhan untuk umat di lingkungan Gerakan Gereja Pantekosta Maranatha Kota Cimahi dan zakat profesi untuk umat di lingkungan Badan Amil Zakat Nasional Kota Cimahi, penulis melakukan pengengamatan pada tindakan umat beragama tersebut sebelum dan sesudah ia melakukan peribadatan. Penelitian ini menggunakan analisis komparatif dalam menarik sebuah kesimpulan.

\section{Hasil dan Pembahasan}

Hasil dan pembahasan penelitian di bawah ini.

\section{Hukum Zakat Profesi dan Persepuluhan}

Dikutip dari wawancara di Gereja Pantekosta Maranatha Cimahi bersama Pdt. Diki, persepuluhan sebagaimana disebutkan dalam Al-Kitab, merupakan salah satu ibadah yang dapat menghantarkan seseorang pada keselamatan dan kebahagiaan (Diki, 2019). Persepuluhan telah dilaksanakan oleh Abraham yang kemudian dilanjutkan oleh Moses. Persepuluhan ini penting karena merupakan dana perbendaharaan Tuhan sekaligus merupakan ibadah pengorbanan hamba terhadap Tuhan (Maleakhi, 3:10).

Menurut Presiden Gereja, Howard W Hunter, awalnya persepuluhan merupakan tradisi orang Lewi, namun kini persepuluhan menjadi sebuah hukum atau perintah Tuhan yang bersifat universal (Howard W. Hunter, 2019).

Sedangkan zakat profesi sebagaimana yang dijelaskan oleh K.H Asep Hilman merupakan zakat atas penghasilan yang diperoleh dari pengembangan potensi diri yang dimiliki seseorang dengan cara yang sesuai syariat, seperti upah kerja rutin, profesi dokter, pengacara, arsitek, dan lain-lain (Mubarok, 2019).

Dari berbagai pendapat dinyatakan bahwa landasan zakat profesi dianalogikan kepada zakat hasil pertanian yaitu dibayarkan ketika mendapatkan hasilnya, demikian juga dengan nishabnya yaitu sebesar 524 $\mathrm{Kg}$ makanan pokok, dan dibayarkan dari pendapatan kotor. Sedangkan tarifnya adalah dianalogikan kepada zakat emas dan perak yaitu sebesar 2,5 \%, atas dasar kaidah "Qias Asysyabah" (Penyusun, 2018).

Berbeda dengan persepuluhan, zakat profesi merupakan kasus baru dalam fiqh Islam karena terbatasnya usaha atau jenis pekerjaan pada zaman dahulu (yang lebih dominan hanyalah bertani, menggembala). Kejadian ini terjadi hingga pada zaman mujtahid besar Islam yakni Imam Abu Hanifah, Imam Malik, Imam Syafi'i, dan Imam Ahmad ibn Hanbal yang dalam kitab-kitab mereka tidak mencantumkan atau membahas mengenai zakat profesi (Agus Marimin, 2015). 
Zakat profesi muncul dengan penggagasnya yaitu Syeikh Yusuf alQaradhawi. Ia menuangkan pendapatnya mengenai zakat profesi dalam kitab Fiqh az-Zakah yang diterbitkan pertama kali pada tahun 1969 (Riasha, 2021). Kemudian zakat profesi masuk dan berkembang di Indonesia awal tahun 2000-an dengan badan atau pengelola zakatnya yaitu BAZDA yang kemudian berubah menjadi BAZNAS (Penyusun, 2018).

Zakat yang dikelola oleh BAZNAS kemudian didistribusikan kepada delapan asnaf sebagaimana landasan hukum pendistribusian zakat Q.S AtTaubah ayat 60 yang artinya "Sesungguhnya zakat-zakat itu, hanyalah untuk orang-orang fakir, orang-orang miskin, pengurus-pengurus zakat, para mu'allaf yang dibujuk hatinya, untuk (memerdekakan) budak, orangorang yang berhutang, untuk jalan Allah dan untuk mereka yang sedang dalam perjalanan, sebagai suatu ketetapan yang diwajibkan Allah, dan Allah Maha mengetahui lagi Maha Bijaksana (At-Taubah, 103).

Pelaksanaan zakat ini diwajibkan atas mereka yang mempunyai pendapatan rutin dan telah mencapai nishab dan haul (Baznas, 2019).

Dalam putusan tarjih Muhammadiyah, zakat adalah harta yang dikeluarkan dari hasil usaha seseorang dengan cara yang baik, halal dan sudah mencapai nishab dan haul zakat (Agus Marimin, 2015).

Menurut sebagian besar ulama, zakat profesi adalah wajib apabila pendapatan tersebut sudah melampaui nisab zakat yakni sebesar $524 \mathrm{~kg}$ makanan pokok, dan dibayarkan dari pendapatan kotor. Sedangkan tarifnya adalah dianalogikan kepada zakat emas dan perak yaitu sebesar 2,5\%, atas dasar kaidah "Qias Asysyabah". Ini juga yang dilakukan oleh BAZNAS Kota Cimahi yang memberikan ruang kepada ASN (Aparatur Sipil Negara) Kota Cimahi yang sudah mencapai nishab dan haul zakat untuk menitipkan zakat profesinya. Ruang tersebut didapatkan setelah adanya kesepakatan bersama antara pimpinan BAZNAS Kota Cimahi dengan Wali Kota Cimahi yang menghasilkan keputusan Nomor 18 tahun 2018. Selain keputusan dan pandangan sebagian besar ulama, pendapat yang lebih konkret juga disebutkan dalam Al-Qur' an Surat al- Baqarah ayat 267 yang dalam tafsir Fii Zhilalil Qur'an karya Sayyid Quthb dijelaskan bahwa " " " " dalam ayat tersebut adalah segala bentuk usaha baik dan halal yang dikeluarkan Allah dari dalam ataupun atas bumi, baik yang terdapat di zaman Rasullullah ataupun zaman setelahnya (Sayyid Quthub, 2021).

Dalam pandangan lain, Syeikh Yusuf al-Qardhawi mewajibkan zakat profesi adalah dengan alasan bahwa pekerja atau profesi pekerjaan zaman sekarang mendapatkan hasil yang bisa melebihi pendapatan petani pada zaman dahulu sehingga banyak ulama yang sepakat bahwa zakat profesi ini wajib ditunaikan (Qardawi., 2007) tidak terkecuali dengan pendapat yang disampaikan oleh K.H Asep Hilman Mubarok sebagaimana yang diungkapkannya dalam wawancara yang telah dilakukan. Ia menilai bahwa zakat profesi ini wajib bagi yang telah memenuhi syarat karena zakat ini 
bisa diandalkan sebagai kekuatan ekonomi umat asalkan zakat yang dikeluarkan tersebut adalah berasal dari hasil yang baik. Lebih jauh Ia menyampaikan bahwa "segala sesuatu yang baik maka yang dikeluarkan atasnya adalah baik. Namun sebaliknya, segala sesuatu yang didapatkan dengan cara yang tidak baik maka yang dikeluarkannya adalah yang tidak baik." Itulah yang berlaku dalam pelaksanaan zakat, segala sesuatu yang dikeluarkan (dizakati) adalah berasal dari hasil usaha yang baik.

Pada prinsipnya, melaksanakan perintah zakat profesi adalah sebuah bentuk ketaatan atas kewajiban membersihkan harta hambanya (Mubarok, 2019). Di samping itu, zakat juga merupakan bentuk ta'awun terhadap sesama. Sama dengan zakat pertanian, zakat profesi juga dikeluarkan setelah mendapatkan hasilnya dengan persentase yang harus dikeluarkan yaitu sebanding dengan zakat emas yakni 2,5\% (Baznas, 2019).

Berbeda dengan zakat profesi yang diberikan sebanyak 2,5\% dari pendapatan kotor seseorang, persepuluhan diberikan sebanyak 10\% dari hasil pendapatan kotor. Persepuluhan ini dianjurkan bahkan ada sebagian yang berpandangan bahwa persepuluhan adalah sebuah kewajiban seorang hamba sebagai bukti ketaatannya pada Tuhan. "Bawalah seluruh persembahan persepuluhan itu ke dalam rumah perbendaharaan, supaya ada persediaan makanan di rumah-Ku dan ujilah $\mathrm{Aku}$, firman Tuhan semesta alam, apakah Aku tidak membukakan bagimu tingkap-tingkap langit dan mencurahkan berkat kepadamu sampai berkelimpahan. Aku akan menghardik bagimu belalang pelahap, supaya jangan dihabisinya hasil tanahmu dan supaya jangan pohon anggur dipadang tidak berbuah bagimu, firman Tuhan semesta alam. Maka segala bangsa akan menyebut kamu berbahagia, sebab kamu ini akan menjadi negeri kesukaan, firman Tuhan semesta alam" (Maleakhi, 3:10).

Persepuluhan menurut Pdt. Diki, dapat dilakukan oleh semua orang mulai dari anak-anak yang menyisakan uang saku sampai dengan orang dewasa yang menyisihkan Persepuluhan dari hasil usahanya dengan tujuan mengembalikan karunia Tuhan. Hasil dari pengumpulan tersebut akan diberikan kepada 4 (empat) golongan yaitu orang Lewi, orang asing, anak yatim serta janda (Diki, 2019).

Adapun definisi hasil dari usaha atau penghasilan tersebut sebagaimana yang dijelaskan oleh Howard W. Hunter didapatkan dari hasil keuntungan, kompensasi, peningkatan. Keuntungan didapatkan dari hasil mereka yang sedang berbisnis, keuntungan dia dari hasil menanam ataupun peningkatan pendapatan yang diraih dari hasil apapun (Howard W. Hunter, 2019).

Selain diberikan kepada 4 (empat) golongan, persepuluhan juga dijadikan sebagai perbendaharaan Gereja yang salah satunya adalah pelayan gereja "Tidak tahukah kamu, bahwa mereka yang melayani dalam tempat kudus mendapat penghidupannya dari tempat kudus itu dan 
bahwa mereka yang melayani mezbah, mendapat bahagian mereka dari mezbah itu?" (Korintus, 9:13). "Mengenai bani Lewi, sesungguhnya Aku berikan kepada mereka segala persembahan persepuluhan di antara orang Israel sebagai milik pusakanya, untuk membalas pekerjaan yang dilakukan mereka, pekerjaan pada Kemah Pertemuan" (Bilangan, 18:21).

\section{Persamaan dan Perbedaan Zakan Profesi dan Persepuluhan}

Dari penjelasan tersebut, dapat kita tarik kesimpulan mengenai persamaan dan perbedaan persepuluhan dan zakat profesi. Pertama, persamaan antara zakat profesi dalam ajaran agama Islam dan persepuluhan dalam ajaran agama Kristen. Keduanya merupakan perintah dari kitab suci. Persepuluhan merupakan sebuah perintah Tuhan terhadap kaumnya (Maleakhi, 3:10). Sedangkan zakat profesi merupakan perintah Allah yang disebutkan dalam Q.S al-Baqarah ayat 267.

Keduanya dianjurkan oleh tokoh agama. Dalam persepuluhan, masih ada pro kontra mengenai pelaksanaan persepuluhan. Namun khususnya pada Gereja Panteskosta Maranatha Kota Cimahi menganjurkan seseorang untuk melaksanakan persepuluhan sebagai bentuk ketaatan terhadap Tuhan dan perbendaharaan gereja. Sedangkan zakat profesi dalam Islam khususnya yang dilakukan di Badan Amil Zakat Nasional Kota Cimahi adalah sebuah kewajiban bagi orang yang sudah memenuhi nishab dan haulnya.

Melaksanakannya adalah sebuah ketaatan terhadap ajaran agama. Seperti yang kita tahu, ketaatan seorang hamba terhadap Tuhannya dapat dilihat dari cara dia melakukan perintah Tuhannya. Siapa yang melaksanakan zakat profesi untuk yang beragama Islam dan siapa yang melaksanakan persepuluhan untuk yang beragama Kristen maka mereka telah taat terhadap perintah Tuhannya.

Salah satu hikmah dari keduanya adalah untuk kepentingan umat atau jemaat. Zakat profesi dan persepuluhan merupakan wujud dari tolong menolong antara satu dengan yang lainnya. Seseorang yang melaksanakan zakat profesi atau persepuluhan biasanya adalah orang yang diberi kecukupan dalam hal material (tidak menutup kemungkinan orang yang kekurangan tapi sempat melaksanakan persepuluhan). Jika mereka melaksanakan persepuluhan atau zakat profesi maka mereka dapat dikatakan telah membantu yang lemah dalam hal material seperti halnya salah satu golongan yang berhak menerima persepuluhan dalam Kristen adalah anak yatim ataupun janda. Sedangkan dalam Islam, salah satu orang yang berhak menerima zakat adalah fakir, miskin.

Pelaksanaannya dihitung dari pendapatan kotor. Pelaksanaan persepuluhan dan zakat profesi diambil dari penghasilan kotor. Meskipun orang tersebut mempunyai banyak pengeluaran, untuk melaksanakan persepuluhan atau zakat profesi ini tetap diambil dari pendapatan kotor. 
Kedua, perbedaan antara zakat profesi dalam ajaran agama Islam dan persepuluhan dalam ajaran agama Kristen. Persepuluhan dapat dilaksanakan oleh siapapun sedangkan zakat profesi hanya bisa dilaksanakan oleh orang yang sudah mencapai nishab dan haulnya. Dalam zakat profesi, seseorang wajib melaksanakan zakat apabila penghasilannya atau pendapatannya telah mencapai nishab dan haul yaitu sebanyak $524 \mathrm{~kg}$ makanan pokok (Penyusun, 2018). Sedangkan dalam Persepuluhan, siapapun dapat melaksanakannya sebagaimana yang dijelaskan oleh Pdt. Diki bahwa anak sekolah pun bisa melaksanakan persepuluhan dengan menyisihkan uang sakunya (Diki, 2019).

Zakat profesi disalurkan pada 8 (delapan) asnaf sedangkan persepuluhan diberikan kepada 4 (empat) golongan. Zakat profesi sebagaimana dijelaskan dalam Al-Qur'an surat at-Taubah ayat 60 . Sedangkan persepuluhan diberikan atau disalurkan hanya kepada 4 (emat) golongan "apabila dalam tahun yang ketiga engkau sudah selesai mengambil segala persembahan persepuluhan dari hasil tanahmu maka haruslah engkau memberikannya kepada orang lewi, orang asing, anak yatim, janda supaya mereka dapat makan di dalam tempatmu dan menjadi kenyang" (Ulangan, 26:12).

Pendistribusian zakat dibagi berdasarkan persentase sedangkan dalam persepuluhan tidak disebutkan persentase pembagiannya. Pendistribusian zakat (termasuk di dalamnya zakat profesi) tidak tanpa perhitungan atau persentasi melainkan delapan asnaf tersebut mempunyai persentasenya yaitu fakir-miskin $60 \%$, amilin $12,5 \%$, muallaf $1 \%$, riqab $0 \%$, ghârimin 0,5\%, ibnu sabîl 0,5\%, dan sabîlillah 25,5\% (Masthuroh, 2013). Berbeda dengan zakat, di dalam persepuluhan tidak disebutkan untuk persentase pendistribusiannya.

Zakat dikeluarkan sebanyak 2,5\% sedangkan persepuluhan dikeluarkan sebanyak $10 \%$ dari penghasilan kotor. Pelaksanaan zakat profesi dilakukan apabila pendapatan seseorang sudah melampaui nisab zakat yakni sebesar $524 \mathrm{~kg}$ makanan pokok yang berhak dikeluarkan zakat atasnya yang dianalogikan kepada zakat emas dan perak yaitu sebesar 2,5\%, atas dasar kaidah "Qias Asysyabah." Sedangkan persepuluhan yang diberikan adalah sebesar $10 \%$ dari pendapatan kotor seseorang.

Persepuluhan bertujuan untuk mengembalikan karunia Tuhan sedangkan zakat profesi bertujuan untuk membersihkan harta. Seseorang yang melaksanakan persepuluhan dilandasi atas ketaatannya untuk mengembalikan karunia Tuhan karena segala sesuatu adalah milik Tuhan sehingga sebagiannya (sepersepuluh) harus dikembalikan kepada Tuhan. Berbeda dengan persepuluhan yang dilandasi sebagai pengembalian karunia Tuhan, zakat profesi bertujuan untuk membersihkan harta.

\section{Implikasi Penerapan Zakat Profesi dan Persepuluhan}


Zakat profesi dan persepuluhan keduanya dilandasi dasar hukum dari dua kitab suci agama tersebut, Islam dan Kristen. Keduanya dapat dikembangkan sebagai ibadah yang berhubungan dengan Tuhan dan sekaligus berhubungan dengan sesama manusia. Dimana agama dipahami sebagai sebuah peraturan yang bersifat mengikat seseorang dalam melaksanakan peribadatan kepada Tuhan Yang Maha Esa (KBBI, 2021). Sedangkan pengembangan zakat profesi dan persepuluhan dapat dilakukan melalui pengelolaan secara profesional oleh masing-masing lembaga dari kedua agama tersebut. Adapun pengaturannya dapat dikendalikan melalui regulasi dari lembaga pemerintahan di Indonesia, sebagaimana zakat profesi telah diatur dalam Peraturan Menteri Agama No. 52 tahun 2014.

Secara prinsip, zakat profesi dalam Islam dan persepuluhan dalam Kristen tidak ada perbedaan. Pelaksanaan keduanya bertujuan sebagai ibadah kepada Tuhan dan demi kesejahteraan sesama umat manusia. Perbedaan keduanya hanya pada masalah teknis saja. Hal ini wajar karena sumber hukum keduanya berbeda yakni zakat profesi didasarkan AlQur'an dan persepuluhan didasarkan al-Kitab. Ketika menafsirkan sumber tersebut dapat terjadi perbedaan pendapat, baik di kalangan ulama Islam maupun di kalangan pendeta Kristen. Perbedaan tersebut tidak perlu dilebarkan karena merupakan persoalan interpretasi. Pastinya bila kedua hal ini tidak dijalankan maka akan memiliki dampak (Ichsan, 2017). Hal yang perlu diambil titik temu terletak pada persamaannya yang bertujuan mensejahterakan umat manusia.

Para pemuka agama berperan melakukan penyuluhan kepada para pemeluk agama masing-masing dalam optimalisasi pelaksanaan zakat profesi di lingkungan umat Islam (Mukhsapak \& Zahid, 2019) dan persepuluhan di lingkungan jemaat Kristiani. Jika hal ini dilakukan, maka penyuluhan ini dapat memiliki implikasi yang besar. Pertama, penguatan keyakinan keimanan umat beragama sebagai bentuk ketaatan kepada Tuhan Yang Maha Kuasa. Kedua, pengembangan praktik keberimanan pemeluk agama Islam dan agama Kristen dalam bentuk kepedulian terhadap sesama manusia demi terciptanya kesejahteraan umat dalam berbagai sektor kehidupan. Ketiga, pengelolaan secara profesional zakat profesi dan persepuluhan sebagai filantropi (Tamim, 2011) yang dapat dikembangkan menjadi sumber ekonomi masyarakat beragama di Indonesia. Diketahui bahwa filantropi agama merupakan subjek yang masih membutuhkan pengembangan di Indonesia (Ulza \& Kurniawan, 2018).

Kenyataan di atas mengindikasikan bahwa semua tuntunan agama mengajarkan kepada kebaikan. Tidak ada alasan terjadi konflik antaragama di Indonesia (Yunus, 2014). Justru antar-pemuka agama harus berusaha mengembangkan dialog dalam memahami ajaran agama masing- 
masing serta diarahkan untuk melakukan kerjasama demi terciptanya kedamaian (Yasin, 2011). Selebihnya, para pemeluk agama dapat melaksanakan ajaran agamanya demi mewujudkan perdamaan dan kesejahteraan. Antara lain dilihat dari penerapan zakat profesi di lingkungan Islam dan persepuuhan di lingkungan Kristen.

\section{Kesimpulan}

Persepuluhan dan zakat profesi merupakan salah satu praktek ibadah. Persepuluhan merupakan salah satu bentuk praktek ibadah dalam Kristen sedangkan zakat profesi adalah salah satu bentuk praktek ibadah dalam Islam. Persepuluhan dianjurkan oleh pendeta dan diwajibkan dalam Maleakhi 3:10-11. Seperti halnya persepuluhan, zakat profesi juga dianjurkan oleh jumhur ulama dan diwajibkan sebagaimana yang disebutkan dalam Q.S al-Baqarah ayat 267. Persamaan antara persepuluhan dalam Kristen dan zakat profesi di dalam Islam adalah keduanya merupakan perintah dari kitab suci, keduanya dianjurkan oleh tokoh agama, melaksanakannya adalah sebuah ketaatan terhadap ajaran agama, dan salah satu hikmah dari keduanya adalah untuk kepentingan umat atau jemaat, dan pelaksanaannya dihitung dari pendapatan kotor. Perbedaannya ialah persepuluhan dapat dilaksanakan oleh siapapun sedangkan zakat profesi hanya bisa dilaksanakan oleh orang yang sudah mencapai nishabnya, zakat profesi disalurkan pada delapan asnaf sedangkan persepuluhan diberikan kepada empat golongan. Pendistribusian zakat dibagi berdasarkan persentase sedangkan dalam persepuluhan tidak disebutkan persentase pembagiannya. Zakat dikeluarkan sebanyak 2,5\% sedangkan persepuluhan dikeluarkan sebanyak $10 \%$ dari penghasilan kotor. Persepuluhan bertujuan untuk mengembalikan karunia Tuhan sedangkan zakat profesi bertujuan untuk membersihkan harta. Diharapkan penelitian ini memiliki implikasi bagi pengembangan kajian studi agama-gama di Indonesia. Diakui penelitian ini memiliki keterbatasan dalam pembahasan zakat profesi dan persepuluhan. Sehingga penelitian ini merekomendasikan penelitian lebih lanjut berkaitan dengan pengembangan zakat profesi dalam agama Islam dan persepuluhan dalam agama Kristen sebagai filantropi agama di Indonesia.

\section{Daftar Pustaka}

Marimin, A., \& Fitria, T. N. (2015). Zakat Profesi (Zakat Penghasila)

Menurut Hukum Islam. Jurnal Ilmiah Ekonomi Islam, 1(01).

Anonim. (2021). jw.org. Retrieved from https://www.jw.org/id/ajaranalkitab/pertanyaan/perpuluhan-di-alkitab/

At-Taubah. (103). 103.

At-Taubah. (103). 
Baznas. (2019). Ketentuan dan Pembagian Zakat Sesuai Syariat Islam. Artikel Baznas Jabar.

Bilangan. (18:21). 21.

Bilangan, K. (18:21). 21.

Darmalaksana, W. (2020). Cara Membuat Proposal Penelitian. Bandung: Fakultas Ushuluddin UIN Sunan Gunung Djati Bandung.

Darmalaksana, W. (2020). Formula Penelitian Pengalaman Kelas Menulis. Jurnal Kelas Menulis UIN Sunan Gunung Djati Bandung. Retrieved from http:/ / digilib.uinsgd.ac.id/32620/

Darmalaksana, W. (2020). Metode Penelitian Kualitatif Studi Pustaka dan Studi Lapangan. Pre-Print Digital Library UIN Sunan Gunung Djati Bandung.

Diki. (2019, Desember 10). Persepuluhan di Gerakan Gereja Pantekosta Maranatha Kota Cimahi. (Gingin, Interviewer)

H.R Bukhori Muslim, H. (n.d.).

Howard W. Hunter. (2019). Ajaran Ajaran Howard W. Hunter. Gereja Yesus Kristus dari Orang-Orang Suci Zaman Akhir, 1-5.

Ibrani. (7:5-18). 5-18.

Ichsan, M. (2017). Zakat Mal dalam Islam dan Persepuluhan dalam Agama Kristen.

Makasar: Repositori Uin Alauddin Makasar.

Imamat, K. (27:30). 30.

KBBI. (2021, Maret 29). Retrieved from https:/ / kbbi.kemdikbud.go.id/entri/agama Kejadian, K. (14:18-20). 18-20.

Kolase. (2:13-14). 13-14.

Korintus. (9:13).

Maleakhi. (3:10). 3.

Maleakhi. (3:10). 10.

Navilah, I. (2013). Persepsi Muzakki tentang Zakat dan Peran Kyai terhadap Upaya Optimalisasi Pengelolaan Dan Pendistribusian Zakat Pada Badan Amil Zakat Kabupaten Cirebon (Studi Kasus tentang Upaya Optimalisasi Pengelolaan dan Pendistribusian Zakat di Kecamatan Astanajapura Kabupaten Cirebon) (Doctoral dissertation, IAIN Syekh Nurjati Cirebon).

Mubarok, A. H. (2019, September 15). Zakat Profesi di Baznas Kota Cimahi. (Gingin, Interviewer)

Zahid, R. A. (2019). Optimalisasi Pemanfaatan Zakat Profesi Kantor Kementerian Agama Kabupaten Kediri Di Sektor Pendidikan. Jurnal Intelektual: Jurnal Pendidikan Dan Studi Keislaman, 9(2), 159-172.

Penyusun, T. (2018). Profil Baznas Kota Cimahi. Cimahi: Baznas Kota Cimahi. Qardawi., Y. (2007). Hukum Zakat. Bogor: Litera Antar Nusa. Riasha, A. F. (2019). Pro Kontra Zakat Profesi, Ada yang Melarang dan 
Ada yang Menghalalkan.

Salossa, D. (2008). Korban Persembahan dan Perpuluhan dengan Pengelolaan Perbendaharaan Rumah Tuhan dalam Sistem Rasuli Perjanjian Baru. Papua.

Sayyid Quthub. (2021). Tafsir Fi Zhilaalil Qur'an di Bawah Naungan AlQur'an, Terj. Fi Zhilalil Qur'an. Beirut: Beirut: Daar el-Surq.

Syafiq, A. (2016). Zakat ibadah sosial untuk meningkatkan ketaqwaan dan kesejahteraan sosial. ZISWAF: Jurnal Zakat dan Wakaf, 2(2), 380-400.

Tafsirq. (2021, 3 29). Retrieved from https:/ / tafsirq.com/2-albaqarah/ayat-267\#tafsir- quraish-shihab

Tamim, I. H. (2011). Peran filantropi dalam pengentasan kemiskinan di dalam komunitas lokal. The Sociology of Islam, 1(1).

Ulangan. (26:12). 12.

Ulza, E., \& Kurniawan, H. (2018). Strategi Pemberdayaan Pembangunan Sosial Melalui Gerakan Filantropi Islam. Al-Urban, 2(1), 32-42.

Yasin, T. H. (2011). Membangun hubungan antar agama mewujudkan dialog dan kerjasama. Substantia: Jurnal Ilmu-Ilmu Ushuluddin, 13(1), 85-91.

Yunus, F. M. (2014). Konflik agama di Indonesia problem dan solusi pemecahannya. Substantia: Jurnal Ilmu-Ilmu Ushuluddin, 16(2), 217-228. 